\title{
Implementasi Sains Teknologi Engineering dan Matematika (STEM) berbasis kewirausahaan budidaya lele dumbo dengan media bioflok dan pakan Bungkil Inti Sawit (BIS) di SMP Purnama Pekanbaru
}

\author{
Yustina ${ }^{*}$, Nursal, Indra Suharman ${ }^{\circledR}$, Arif Riandra, Oky Priawan, dan Winda Sari \\ Universitas Riau \\ * hj_yustin@yahoo.com
}

\begin{abstract}
Abstrak. Pengabdian pada Masyarakat (P2M) ini bertujuan untuk mengetahui kemampuan siswa dalam Implementasi Sains Teknologi Engeenering dan Matematika (STEM) Berbasis Kewirausahaan Budidaya Lele Dumbo dengan Media Bioflok dan Pakan Buatan Bungkil Inti Sawit (BIS). Kegiatan P2M dilakukan di SMP Purnama Pekanbaru melalui kegiatan pembelajaran Ekstrakurikuler pada bulan Maret sampai Juni 2019. Peserta sebanyak 20 orang siswa yang terdiri dari 4 kelompok. Metode kegiatan pendekatan STEM dengan model Project Based Learning (PjBL) ini terdiri dari 3 tahapan yaitu: 1.Persiapan: pelatihan pembuatan bioflok, pembuatan pakan dan pengadaan benih; 2. Pelaksanaan: perlakuan, pemeliharaan, pengawasan dan koleksi data pertumbuhan, biaya operasional: 3. Analisis data ekonomi kewirausahaan dan kemampuan STEM. Instrumen pengumpulan data pertumbuhan dan biaya operasional menggunakan logbook dan lembar observasi. Data Kemampuan STEM dan Kewirausahaan menggunakan Lembar Kerja Peserta Didik (LKPD). Data pertumbuhan ikan dan biaya operasional, selanjutnya dipersentase, diskor, ditabulasi dan dianalisis secara deskriptif. Hasil kemampuan STEM yang diperoleh yaitu kemampuan Sains dengan skor 80 (kategori baik); kemampuan Engeenering 50 (kategori kurang), kemampuan Teknologi dengan skor 60 (kategori cukup) dan kemampuan Matematika dengan skor 65 (kategori cukup). Analisis ekonomi kewirausaahan dengan skor 75 (kategori cukup) dan 50\% peserta mendapatkan keuntungan sebesar $30 \%$ dari produksi panen lele dalam waktu 3 bulan.
\end{abstract}

Kata kunci: bioflok; budidaya; ikan lele; pakan; teknologi; wirausaha

\begin{abstract}
Community Service aims to determine the ability of students in the Implementation of Science Technology Engeenering and Mathematics (STEM) Based on Entrepreneurship of Dumbo Catfish Cultivation with Bioflok and Feed Media made by Palm Kernel Oil (BIS). P2M activities are conducted at Pekanbaru Purnama Middle School through Extracurricular learning activities from March to June 2019. Participants are 20 students consisting of 4 groups. The method of using the STEM approach with the Project Based Learning (PjBL) model consists of 3 stages, namely: 1. Preparation: bioflok making training, feed making and seed procurement; 2. Implementation: treatment, maintenance, supervision and collection of growth data, operational costs: 3. Analysis of entrepreneurial economic data and STEM capabilities. Instrument for collecting growth data and operational costs using logbooks and observation sheets. Data on STEM and Entrepreneurship Capabilities using Student Worksheets. Data on fish growth and operational costs, then percentage, were scaled, tabulated and analyzed descriptively. The results of STEM abilities were obtained namely Science ability with a score of 80 (good category); Engeenering 50 ability (less category), Technology ability with a score of 60 (sufficient category) and Mathematical ability with a score of 65 (sufficient category). Entrepreneurial economic analysis with a score of 75 (sufficient category) and $50 \%$ of participants get a profit of $30 \%$ from catfish production within 3 months.
\end{abstract}

Keywords: bioflok; cultivation; catfish; feed; technology; entrepreneurship 
To cite this article: Yustina, Nursal, I. Suharman, A. Riandra, O. Priawan, \& W. Sari. 2019. Implementasi Sains Teknologi Engineering dan Matematika (STEM) berbasis kewirausahaan budidaya lele dumbo dengan media bioflok dan pakan Bungkil Inti Sawit (BIS) di SMP Purnama Pekanbaru. Unri Conference Series: Community Engagement 1: 401-410 https://doi.org/10.31258/unricsce.1.401-410

(C) 2019 Authors

Peer-review under responsibility of the organizing committee of Seminar Nasional Pemberdayaan Masyarakat 2019

\section{PENDAHULUAN}

Salah satu contoh limbah padat dari hasil produksi buah sawit yaitu berupa bungkil inti sawit (BIS). Selama ini manfaat BIS kurang begitu diperhatikan. BIS memiliki nilai ekonomis yang sangat tinggi jika dimanfaatkan dengan benar. Salah satu pemanfaatannya yang perlu diteliti yaitu menjadi subtitusi atau bahan pakan alternatif untuk usaha perikanan. Pakan merupakan faktor yang memegang peranan sangat penting dan menentukan dalam keberhasilan usaha perikanan dan ketersediaan pakan merupakan salah satu faktor utama untuk menghasilkan produksi maksimal (Darmawijayanti, 2005). Penggunaan BIS sebagai pakan dapat menekan biaya produksi sehingga keuntungan yang didapatkan akan semakin besar. Oleh karena itu pakan ikan perlu dijamin ketersediaanya sesuai dengan jumlah dan mutu yang dibutuhkan.

Sumber utama protein bagi ikan adalah pakan. baik pakan alami maupun buatan. Apabila kandungan protein dalam pakan tidak memenuhi kebutuhan ikan, maka pertumbuhan akan terhambat. Ikan membutuhkan lebih banyak protein dibandingkan dengan Mamalia. Salah satu protein nabati yang dapat digunakan sebagai pakan ikan yaitu bungkil inti kelapa sawit (Rachmatun, 2001).

Bungkil inti sawit (BIS) ini telah umum dimanfaatkan sebagai sumber bahan pakan, namun bahan pakan tersebut mempunyai faktor pembatas, yaitu kandungan serat yang cukup tinggi dan kualitas protein yang kurang baik, sehingga perlu diolah agar lebih bermanfaat bagi pembudidayaan ikan. Serat kasar yang tinggi diketahui dapat mengurangi ketersediaan energi dan zat makanan lain serta mempengaruhi kecepatan aliran bahan makanan dalam saluran pencernaan (Siri et al., 1992, dalam Mairizal, 2013). Salah satu bentuk pengelolaan BIS adalah dengan cara fermentasi dengan kapang Aspergillus niger.

Usaha perikanan yang umumnya diminati oleh masyarakat yaitu ternak ikan lele (Clarias sp.). Tingginya minat ternak ikan lele pada umumnya disebabkan oleh beberapa faktor seperti: 1) ikan lele memiliki pangsa pasar yang luas. Umumnya ikan lele banyak diminati oleh berbagai kalangan usia, sehingga permintaan akan kebutuhan ikan lele sangat besar; 2) Perawatannya relatif mudah. Ikan lele termasuk jenis ikan yang mudah beradaptasi dengan lingkungannya, baik di kolam tanah, semen, atau terpal. Dimanapun tempat tinggalnya, ikan lele mampu bertahan hidup dan berkembang biak dengan baik; 3) Lebih tahan dari penyakit. Beberapa jenis ikan yang dibudidayakan biasanya rentan terhadap serangan penyakit, namun tidak bagi ikan lele. Ikan lele terkenal akan ketahanannya terhadap serangan penyakit dan memiliki kekebalan tubuh yang baik; 4) Dapat dipanen lebih cepat, karena ikan lele sudah siap panen sekitar 3 bulan sejak benih ditebar; 5) Benih lebih mudah didapat dan harganya murah.

Kelurahan Sidomulyo Timur merupakan daerah dengan status pemerintahan kelurahan yang berada pada Kecamatan Marpoyan Damai, Kota Pekanbaru, Provinsi Riau. Luas Kelurahan Sidomulyo Timur adalah 719 Ha. Pada tahun 2016, desa ini berpenduduk sebesar 26.704 jiwa dengan kepadatan penduduk 3.714 jiwa $/ \mathrm{km}^{2}$. Potensi demografi antaralain jumlah usia milinial (remaja) sekitar 30\% dan letak lokasi yang strategis secara perekonomian, terutama dalam usaha budidaya ikan dan usaha makanan kuliner. Kecenderungan permasalahan ekonomi keluarga merupakan tantangan bagi kelangsungan pendidikan para remaja, khususnya remaja di jenjang pendidikan tingkat Sekolah Menengah Pertama (SMP).

Salah satu sekolah yang dimanfaatkan warga tempatan dalam pendidikan remaja ditingkat pendidikan sekolah menengah pertama yaitu di SMP Purnama. Keterampilan hidup (Life skill) seperti kewirausahaan sangat diperlukan bagi siswa, agar dapat mendukung atau persiapan yang diperlukan untuk kelanjutan pendidikan siswa kelak. Maka dari itu sekolah memberikan kegiatan ekstrakurikuler yang dapat menunjang proses pembelajaran Bioteknologi dan kewirausahaan untuk Life skill siswa. Hal ini diperlukan pendampingan pembinaan, salah satunya melalui kegitan tim pengabdian P2M yang berkolaborasi dengan peserta kuliah kerja nyata (KUKERTA) Universitas Riau dan bermitra dengan SMP Purnama yaitu melalui pendampingan pembinaan budidaya ikan lele dan pembuatan pakan ikan menggunakan Bungkil Inti Sawit (BIS) dengan 
media Bioflok. Pelaksanaan Kegiatan pengabdian ini menggunakan model Projek Based Learning (Pj_BL) dengan pendekatan Sains Teknologi Engineering dan Matematika (STEM ) berbasiskan Kewirausahaan.

STEM memiliki keunggulan karena pendekatan yang mengintegrasikan lingkungan, teknologi dan masyarakat lainnya. Pendekatan STEM adalah sebuah pembelajaran yang mengintegrasikan konten dan keterampilan ilmu pengetahuan, teknologi, teknik dan matematika. Tujuan dari pendekatan STEM adalah mempersiapkan peserta didik untuk tiang ilmu sekunder dan keahlian kerja abad 21 (Denis, 2016). Beers (2011) mengemukakan bahwa kurikulum STEM melibatkan "4C" dari keterampilan abad 21, yaitu meliputi creativity (kreatifitas), critical thinking (berpikir kritis), collaboration (kolaborasi), dan communication (komunikasi). Peserta didik bekerja sama untuk menciptakan solusi inovatif pada masalah nyata dan mengkomunikasikannya dengan orang lain.

Adapun tujuan kegiatan ini dilaksanakan adalah: 1) Memberikan informasi dan pengetahuan kepada siswa untuk bagaimana cara budidaya lele dengan sistem bioflok. 2) Mengembangkan jiwa kreativitas siswa dengan memanfaatkan potensi sumber daya alam khususnya mengolah limbah bungkil sawit menjadi pakan ikan. 3) Melalui pelatihan ini diharapkan dapat memberikan nilai tambah dan meningkatkan pendapatan dan minat, khususnya untuk berwirausaha di bidang budidaya ikan lele dikalangan siswa dan masyarakat sekolah umumnya. 4) Mengimplementasikan pendekatan STEM dan kewirausahan di kalangan siswa pada kegiatan ekstra kurikuler.

\section{MASALAH}

Pengangguran dan permasalahan ekonomi masyarakat semakin meningkat ditambah dengan urbanisasi masyarakat desa yang massive dapat menimbulkan masalah baru, sehingga perlu munculnya inovasi terbaru dalam meminimalkan pengangguran. Penggunaan lahan yang tidak begitu luas dapat dimanfaatkan sebagai peluang usaha yaitu budidaya ikan lele sistem bioflok. Selain keterbatasan lahan, kita ketahui bahwa terdapat masyarakat yang masih belum memiliki keterampilan dalam budidaya ikan lele sistem bioflok. Disamping itu, masyarakat khususnya dikalangan siswa juga belum memiliki pengalaman dalam budidaya ikan di lahan terbatas, penyediaan benih/bibit, menyiapkan media dan teknik pemeliharaan yang baik serta pengolahan pakan ikan dengan memanfaatkan limbah bungkil sawit dapat dijadikan kegiatan usaha ekonomi (kewirausahaan). Kewirausahaan merupakan suatu upaya kegiatan secara individu maupun berkelompok yang fokus pada suatu peluang uhasa yang dapat berkontibusi dalam perbaikan ekonomi siswa dan keluarga.

\section{METODE}

Kegiatan P2M dilakukan di SMP Purnama Pekanbaru melalui kegiatan pembelajaran Ekstrakurikuler pada bulan Maret sampai Juni 2019. Peserta sebanyak 20 orang ibu dari perwakilan pengurus PKK, orang tua siswa, guru sebagai peserta pemantau, dan 20 orang siswa. yang terdiri dari 4 kelompok dan setiap kelompok terdiri dari 5 orang siswa. Metode kegiatan pendekatan STEM dengan model Project Based Learning (PjBL) ini terdiri dari 3 tahapan yaitu:1. Persiapan: pelatihan pembuatan bioflok, pembuatan pakan dan pengadaan benih; 2. Pelaksanaan: perlakuan, pemeliharaan, pengawasan dan koleksi data pertumbuhan, biaya operasional: 3 . Analisis data kemampuan STEM dan kewirauhahaan siswa. Instrumen pengumpulan data pertumbuhan dan biaya operasional menggunakan logbook dan lembar observasi. Kemampuan STEM dan kewirausahaan siswa menggunakan Lembar Kerja Peserta Didik (LKPD). Data pertumbuhan ikan dan biaya operasional selanjutnya dipersentase, dihitung skor, ditabulasi dan dianalisis secara deskriptif.

\section{Prosedur Kegiatan}

Ikan yang digunakan dalam kegiatan $\mathrm{P} 2 \mathrm{M}$ ini adalah benih ikan lele dumbo (C. gariepinus) dengan ratarata

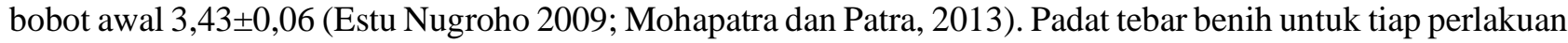
dan ulangan sebanyak 1 ekor/2 L air (Yunus et al., 2014). Wadah yang digunakan adalah bioflok diameter $2 \mathrm{~m}$, tinggi $1 \mathrm{~m}$ dan diisi air sebanyak 50\% dari kapasitas wadah, dilengkapi dengan aerasi untuk mensuplai oksigen dalam air (Madinawati et al., 2011). Tahap pengujian pakan dilakukan selama 56 hari (Estu Nugroho 2009; Sogbesan et al., 2015). Frekuensi pemberian pakan sebanyak 3 kali yaitu pagi, siang, dan sore hari secara at satiation (SNI, 2000). Setiap 3 hari sekali dilakukan penyiponan untuk membuang sisa pakan dan kotoran ikan (Madinawati et al., 2011).

Pakan ikan yang digunakan adalah pakan buatan yang dibuat sendiri menggunakan bahan baku lokal yaitu tepung limbah BIS, tepung limbah sayur sawi dan kol, tepung ikan, dedak, tepung kepala udang, air, ampas 
tahu, dan mineral-mineral. Tepung limbah BIS dibuat dengan melakukan fermentasi menggunakan kapang Rhizopus oligosporus.

Proses penentuan formulasi pakan dalam pembuatan pakan uji didasarkan pada kebutuhan protein dari ikan uji, dimana kebutuhan protein dari ikan lele dumbo yaitu 25,30\% (SNI, 2000). Pembuatan pakan diawali dengan pencampuran bahan pakan dari jumlah yang terkecil sampai yang terbesar dan diaduk hingga homogen, kemudian ditambahkan air hangat sebanyak 35,40\% dari total bahan. Penambahan air dilakukan sambil bahan diaduk sampai merata dan kalis, sehingga bisa dibuat gumpalan-gumpalan untuk dicetak menggunakan gilingan dan dikeringkan menggunakan oven dengan suhu $<500^{\circ} \mathrm{C}$ atau dijemur, sampai kadar air pakan konstan.

Siswa melaporkan bahan diskusi dalam LKPD melalui pendekatan STEM, dengan kisi-kisi penilaian, aspek STEM, aspek kewirausahaan dan indikator, bobot nilai (Tabel 1).

Tabel 1. Kisi-kisi Penilaian Aspek STEM dan Wirausaha pada LKPD dengan Pendekatan STEM

\begin{tabular}{clcc}
\hline Aspek STEM & \multicolumn{1}{c}{ Indikator dari masing-masing aspek } & $\begin{array}{c}\text { Bobot } \\
\text { Nilai }\end{array}$ & $\begin{array}{c}\text { Skor per } \\
\text { Aspek }\end{array}$ \\
\hline Sains & Pertumbuhan Panjang & 20 & 100 \\
metoda ilmiah) & Pertumbuhan Berat & 20 & \\
& Kelulusan hidup & 20 & \\
& Laju Pertumbuhan & 20 & \\
& Konversi pakan & 20 & \\
\hline \multirow{2}{*}{ Teknologi } & Menentukan alat \& bahan & 20 & 100 \\
& Formulasi pakan buatan BIS & 20 & \\
& Mengoperasionalkan alat & 20 & \\
& Mengoperasionalkan program exel mengolah data & 20 & \\
& Presentase \& tampilan data, pelaporan & 20 & \\
\hline \multirow{2}{*}{ Engineering } & Mendesain Bioflok & 50 & 100 \\
& Mengkonstruk Bioflok & 50 & \\
\hline \multirow{2}{*}{ Matematika } & Menghitung biaya pembuatan bioflok & 20 & 100 \\
& Menghitung biaya pembuatan pakan BIS & 20 & \\
& Menghitung pertumbuhan, konversi pakan, kelulusan hidup & 20 & \\
& Menghitung teknik operasional & 20 & \\
& Menghitung biaya operasional & 20 & \\
\hline \multirow{2}{*}{ Wirausaha } & Memprediksi peluang & 25 & 100 \\
& Memprediksi tantangan dan kendala & 25 & \\
& Memprediksi keuntungan & 25 & \\
& Memprediksi respons pengguna/masyarakat & 25 & \\
\hline
\end{tabular}

\section{HASIL KEGIATAN}

Hasil kegiatan P2M penerapan pendekatan STEM menggunakan model pembelajaran PjBL dalam usaha budidaya ikan Lele dan pakan BIS meliputi aspek Sains, Teknologi, Engineering, Matematika dan kewirausahaan diuraikan sebagai berikut.

\section{Kemampuan Sains}

Kemampuan aspek Sains dalam kegiatan P2M ini adalah pertumbuhan ikan Lele dengan pakan BIS dari nilai LKPD pendekatan STEM dan Kewirausahaan pada media Bioflok disajikan pada Tabel 2. 
Tabel 2. Skor Aspek Sains dari Penilaian LKPD dengan Pendekatan STEM

\begin{tabular}{lccccc}
\hline \multirow{2}{*}{\multicolumn{1}{c}{ Indikator Aspek Sains }} & \multicolumn{4}{c}{$\begin{array}{c}\text { Skor kemampuan Sains pada Kelompok dan Perlakuan } \\
\text { pada pakan }\end{array}$} & \multicolumn{2}{c}{$\begin{array}{c}\text { Rata-rata } \\
\text { Skor }\end{array}$} \\
\cline { 2 - 4 } & $1 \mathrm{~A}$ & $2 \mathrm{~A}$ & $3 \mathrm{~B}$ & $4 \mathrm{~B}$ & \\
\hline Pertumbuhan Panjang & 20 & 20 & 20 & 20 & 20 \\
Pertumbuhan Berat & 20 & 20 & 20 & 20 & 20 \\
Kelulusan hidup & 20 & 20 & 20 & 20 & 20 \\
Laju Pertumbuhan & 10 & 5 & 5 & 5 & 8,75 \\
Konversi pakan & 20 & 20 & 20 & 15 & 16,25 \\
\hline Skor Kemampuan Sains per Kelompok & 90 & 85 & 85 & 80 & 85 \\
\hline
\end{tabular}

Keterangan: A: Pakan dengan kandungan BIS sebanyak 8\%; B: Pakan dengan kandungan BIS sebanyak 12\%

Kemampuan rata-rata sains siswa dengan skor 85 (kategori baik), perincian kemampuan sais siswa dari keempat kelompok siswa, menunjukkan skor tertinggi (90) dikategorikan sangat baik di kelompok 1, dan terendah dengan skor (80) dikategorikan baik yaitu pada kelompok 4.

Dari kelima aspek sains yang ditinjau dari kelima indikator sains, didapat rerata skor terendah yaitu pada laju pertumbuhan dengan rata-rata skor pada indikator laju pertumbuhan dengan rata-rata skor 8,75 , sedangkan 4 aspek sains yang lain pengukuran berat, panjang, kelulusan hidup masing dengan skor 20 dan skor 16,25 pada aspek sains konversi pakan.

\section{Kemampuan Teknologi}

Kemampuan teknologi berdasarkan target dan indikator penilaian dari aspek teknologi disajikan pada Tabel 3. Kemampuan teknologi siswa dari 4 kelompok dengan rata-rata skor 60 (kategori cukup) yaitu diantaranya tiga kelompok (75\% siswa) mendapat skor antara 60 sampai 65 (dikategorikan cukup), dan 1 kelompok dengan skor 55 (25\% siswa) dikategorikan kurang kemampuan teknologinya. Indikator aspek teknologi tertinggi adalah menentukan alat dan bahan dengan rata-rata skor maksimal 20, dan skor terendah adalah mengoperasionalkan program exel mengolah data dengan rata-rata skor 8,75.

Tabel 3. Skor Aspek Teknologi dari penilaian LKPD dengan pendekatan STEM

\begin{tabular}{|c|c|c|c|c|c|}
\hline \multirow{2}{*}{ Indikator Aspek Teknologi } & \multicolumn{4}{|c|}{$\begin{array}{l}\text { Kemampuan Teknologi dari LKPD pendekatan STEM dan } \\
\text { Kewirausahaan pada Kelompok }\end{array}$} & \multirow{2}{*}{$\begin{array}{l}\text { Rata-rata } \\
\text { Skor }\end{array}$} \\
\hline & 1 & 2 & 3 & 4 & \\
\hline Menentukan alat $\&$ bahan & 20 & 20 & 20 & 20 & 20 \\
\hline Formulasi pakan buatan BIS & 10 & 10 & 10 & 10 & 10 \\
\hline Mengoperasionalkan alat & 10 & 15 & 10 & 10 & 11,25 \\
\hline $\begin{array}{l}\text { Mengoperasionalkan program exel } \\
\text { mengolah data }\end{array}$ & 10 & 10 & 10 & 5 & 8,75 \\
\hline Presentase \& tampilan data, pelaporan & 10 & 10 & 10 & 10 & 10 \\
\hline $\begin{array}{l}\text { Skor Kemampuan Teknologi per } \\
\text { Kelompok }\end{array}$ & 60 & 65 & 60 & 55 & 60 \\
\hline
\end{tabular}

\section{Kemampuan Engineering}

Target kegiatan dari indikator aspek teknologi adalah siswa terampil secara berkelompok untuk mendesain dan mengkonstruksi bioflok sebagai media pembudidayaan ikan lele (Tabel 4). 
Tabel 4. Skor Aspek Engineering dari penilaian LKPD dengan pendekatan STEM

\begin{tabular}{lccccc}
\hline \multirow{2}{*}{$\begin{array}{l}\text { Indikator Aspek Engineering } \\
\text { Mendesain Bioflok }\end{array}$} & \multicolumn{4}{c}{$\begin{array}{c}\text { Kemampan Engineering dari LKPD pendekatan STEM } \\
\text { dan Kewirausahaan pada Kelompok }\end{array}$} & $\begin{array}{c}\text { Rata-rata } \\
\text { Skor }\end{array}$ \\
\cline { 2 - 5 } & 1 & 2 & 3 & 4 & 25 \\
Mengkonstruk Bioflok & 30 & 20 & 30 & 20 & 25 \\
\hline Skor Engineering per Kelompok & 30 & 30 & 20 & 20 & 50 \\
\hline
\end{tabular}

Kemampuan Engineering dengan rata-rata skor 50 (kategori kurang), yaitu diantaranya satu kelompok (25\% siswa) mendapat skor 60 (dikategorikan cukup), dua kelompok (75\% siswa) mendapat skor 40-50 dikategorikan kurang kemampuan engineerignya.

\section{Kemampuan Matematika}

Target kegiatan dari aspek matematika adalah siswa dapat menghitung ukuran disain teknis dan biaya operasional kegiatan budidaya ikan lele, pembuatan pakan (aspek Matematika) dapat dilihat pada Tabel 5.

Tabel 5. Skor Aspek Matematika dari penilaian LKPD dengan pendekatan STEM

\begin{tabular}{|c|c|c|c|c|c|}
\hline \multirow[t]{2}{*}{ Aspek Matematika } & \multicolumn{4}{|c|}{$\begin{array}{l}\text { Skor kemampuan Matematika dari LKPD pendekatan } \\
\text { STEM dan Kewirausahaan pada Kelompok }\end{array}$} & \multirow{2}{*}{$\begin{array}{l}\text { Rata-rata } \\
\text { Skor }\end{array}$} \\
\hline & 1 & 2 & 3 & 4 & \\
\hline Menghitung biaya pembuatan bioflok & 15 & 10 & 10 & 10 & 11,25 \\
\hline $\begin{array}{l}\text { Menghitung biaya pembuatan pakan } \\
\text { BIS }\end{array}$ & 20 & 15 & 10 & 15 & 15 \\
\hline $\begin{array}{l}\text { Menghitung pertumbuhan, konversi } \\
\text { pakan, kelulusan hidup }\end{array}$ & 15 & 10 & 20 & 20 & 16,25 \\
\hline Menghitung teknik operasional & 10 & 10 & 10 & 5 & 8,75 \\
\hline Menghitung biaya operasional & 10 & 15 & 15 & 15 & 13,75 \\
\hline $\begin{array}{l}\text { Skor Kemampuan Matematika per } \\
\text { Kelompok }\end{array}$ & 70 & 60 & 65 & 65 & 65 \\
\hline
\end{tabular}

Kemampuan matematika diperoleh rata-rata skor 65 (kategori cukup), yaitu diantaranya satu kelompok ( $25 \%$ siswa) mendapat skor 70 (dikategorikan baik), tiga kelompok (75\% siswa) mendapat skor 60-65 dikategorikan cukup kemampuan matematikanya.Kemampuan rata-rata Matematika dengan skor 65 (kategori cukup). Indikator terendah adalah menghitung teknik operasional dengan ratarata skor 8.75 .

\section{Kemampuan Kewirausahaan}

Target kewirausahaan yaitu siswa mampu menganalisis anggaran biaya investasi, biaya operasional, dan keuntungan panen ikan Lele dari kegiatan, kendala dan memprediksi tantangan dan peluang serta memprediksi respon masyarakat terhadap kegiatan usaha budidaya ikan lele. Skor aspek kewirausahaan dapat dilihat pada Tabel 6.

Kemampuan wirausaha diperoleh rata-rata skor 75 (kategori baik), yaitu diantaranya satu kelompok (25\% siswa) mendapat skor 80 (dikategorikan sangat baik), tiga kelompok (75\% siswa) mendapat skor 70-75 dikategorikan baik kemampuan wirausahanya. Indikator dengan rata-rata skor tertinggi adalah memprediksi keuntungan. Indikator terendah yaitu memprediksi respons pengguna masyarakat $(8,75)$. 
Tabel 6. Skor Aspek Kewirausahaan dari penilaian LKPD dengan pendekatan STEM

\begin{tabular}{lccccc}
\hline \multirow{2}{*}{ Indikator Aspek Wirausaha } & \multicolumn{3}{c}{ Skor kemampuan Wirausaha pada Kelompok } & \multirow{2}{*}{$\begin{array}{c}\text { Rata-rata } \\
\text { Skor }\end{array}$} \\
\cline { 2 - 5 } & $1 \mathrm{~A}$ & $2 \mathrm{~A}$ & $3 \mathrm{~B}$ & $4 \mathrm{~B}$ & 22,5 \\
Memprediksi peluang & 25 & 25 & 20 & 20 & 18,75 \\
Memprediksi tantangan dan kendala & 20 & 20 & 15 & 20 & 25 \\
Memprediksi keuntungan & 25 & 25 & 25 & 25 & 8,75 \\
Memprediksi respons & 10 & 5 & 15 & 5 & 75 \\
pengguna/masyarakat & & & & 70 & \multirow{2}{*}{75} \\
\hline Skor Kemampuan Wirausaha per & 80 & 75 & &
\end{tabular}

\section{PEMBAHASAN}

Pembahasan pada hasil kegiatan ini, hanya fokus pada hasil yang kemampuan dikategorikan baik, yaitu kemampuan sains dan kewirausahaan, sedangkan ketiga aspek lainnya dengan kemampuan kurang dan sedang tidak dibahas. Kemampuan sains dari indikator konversi pakan, kelulusan hidup ikan peliharaan diperoleh dari uraian berikut ini.

Konversi Pakan (FCR), konversi pakan adalah perbandingan pakan yang habis dengan pertambahan bobot yang dihasilkan selama pemeliharaan. Tinggi rendahnya konversi pakan, merupakan gambaran efesiensi pemberian pakan yang digunakan dalam kegiatan ini. Hasil perhitungan konversi pakan benih ikan lele selama pemeliharaan pada kedua perlakuan tercantum pada Tabel 7.

Tabel 7. Konversi Pakan Benih Ikan Lele Selama Pemeliharaan

\begin{tabular}{ccc}
\hline \multirow{2}{*}{ Waktu Perlakuan (hari) } & \multicolumn{2}{c}{ Konversi Pakan per Kandungn Pakan BIS } \\
\cline { 2 - 3 } & A (Kandungan pakan BIS 8\%) & B (Kandungan pakan BIS 12\%) \\
\hline 3 minggu (21 hari) & 3.10 & 3.36 \\
6 minggu (42 hari) & 3,72 & 4,32 \\
9 minggu (63 hari) & 4,11 & 5,1 \\
\hline Rata-rata & 3,65 & 4,26 \\
\hline
\end{tabular}

Rata-rata konversi pakan dapat dilihat pada Tabel-7, pemberian pakan yang mengandung fermentasi BIS didapat nilai rata-rata konversi pakan yang lebih baik pada perlakuan A dengan rata-rata konversi $(3,65)$ dibandingkan konversi pakan pada perlakuan B $(4,26)$. Penambahan fermentasi bungkil kelapa sawit $8 \%$ kedalam pakan lebih baik tehadap konversi pakan yang menggunakan bungkil kelapa sawit $12 \%$. Jumlah konsumsi pakan sangat erat hubungannya dengan kandungan protein dan energi dalam pakan, semakin rendah nilai konversi pakan maka semakin baik kualitas pakan tersebut, ini mengindikasikan bahwa ikan lele lebih menyukai pakan dengan kandungan serat lebih rendah. Pendapat Djajasewaka (1985) dalam Sonata et.al (2014) menyatakan bahwa konversi pakan erat hubunganya dengan pertumbuhan nilai konversi pakan. Dihitung untuk menentukan baik atau tidaknya kualitas pakan yang dihasilkan bagi pertumbuhan. Semakin rendah nilai konversi pakan maka semakin baik kualitas pakan tersebut dan pakan yang diberikan dapat dimanfaatkan oleh ikan untuk pertumbuhan. Menurut Mudjiman (2002) faktor konversi pakan pada ikan berkisar 2-8. Hasil riset Sonata et.al, (2014), menunjukkan bahwa pakan dengan kandungan protein 28-30\% dengan jumlah pemberian pakan 3\%. Dalam menyusun formulasi pakan harus sesuai dengan tipe ikan yang dipelihara hal ini erat kaitanya dengan konversi pakan (Sonata et.al, 2014).

Kelangsungan hidup pada ikan lele yang tertinggi terdapat pada perlakuan A $(90,00 \%)$, diikuti dengan perlakuan B $(86,67 \%)$. Adapun faktor- faktor yang mempengaruhi mortalitas benih adalah ketersediaan makanan baik kualitas maupun kuantitasnya. Sesuai dengan pendapat Effendi (1997) bahwa tingginya mortalitas disebabkan oleh faktor lingkungan yang tidak sesuai seperti $\mathrm{pH}$ perairan, suhu, tidak tersedianya pakan serta kerusakan fisik akibat penanganan yang kurang hati- hati selama pemeliharaan 
Pemenuhan target produksi budidaya ikan lele dapat dicapai salah satunya dengan cara budidaya ikan secara intensif. Budidaya intensif meminimalisir ketergantungan terhadap pakan alami, sehingga pakan buatan menjadi satu-satunya sumber makanan bagi organisme yang dipelihara (Ekasari, 2009). Pakan merupakan salah satu unsur penting dalam kegiatan budidaya yang menunjang pertumbuhan dan kelangsungan hidup ikan budidaya. Pakan pada kegiatan budidaya umumnya adalah pakan komersial yang menghabiskan sekitar 60$70 \%$ dari total biaya produksi yang dikeluarkan (Handajani, 2006).

Kebutuhan gizi pada ikan berkaitan erat dengan kebutuhan energi total (baik yang berasal dari protein, maupun yang berasal dari karbohidrat dan lemak). Zat gizi pakan dan pertumbuhan ikan merupakan faktor pembatas dalam suatu model pertumbuhan. Daya cerna adalah bagian pakan yang dikonsumsi dan tidak dikeluarkan menjadi feses. Kapasitas lambung dan laju pakan dalam saluran cerna merupakan variabel dari daya cerna. Ikan yang berbobot lebih kecil akan mengosongkan sejumlah pakan dari dalam lambungnya lebih cepat dibanding ikan yang berbobot besar.

Aspek sains terendah pada indikator menghitung laju pertumbuhan, karena siswa harus memahami konsep pertumbuhan dan terampil menghitung laju pertumbuhan berdasarkan formulasi rumus dan pengetahuan kompleks. Hal ini menuntut kemampuan berpikir kritis dengan tingkatan pemahaman dan wawasan lebih luas dibandingkan dari keempat indikator aspek sains lainnya yang belum terperinci diberikan pada tingkat pengembangan berpikir siswa di SMP. Pemahaman terperinci tentang indikator laju pertumbuhan diuraikan sebagai berikut.

Laju pertumbuhan adalah perubahan ukuran tubuh yang dapat berupa panjang atau berat suatu organisme dalam waktu tertentu (Effendie, 1997). Laju Pertumbuhan terdiri dari laju pertumbuhan spesifik dan laju pertumbuhan harian.

Pertumbuhan Spesifik, adapun rumus dalam menghitung laju pertumbuhan spesifik berat ikan lele menurut Fitriadi et al. (2014) adalah sebagai berikut:

$$
\mathrm{SGR}=(\ln \mathrm{Wt}-\ln \mathrm{Wo}) / \mathrm{t} \times 100 \%
$$

Keterangan: $S G R=$ Laju pertumbuhan Spesifik (\%); Wt = Berat rata-rata akhir penelitian $(g) ;$ Wo = Berat rata-rata awal penelitian $(\mathrm{g}) ; t=$ Lama pemeliharaan (hari)

Laju Pertumbuhan Harian, laju pertambahan panjang harian benih ikan, digunakan rumus De Silva dan Anderson (1995) dalam Farida et al., 2016 yaitu:

$$
\mathrm{L}=(\ln \mathrm{Lt}-\ln \mathrm{Lo}) / \mathrm{t} \times 100 \%
$$

Keterangan: $L=$ Laju pertambahan panjang harian; Lt= panjang akhir; Lo= panjang awal; $t=$ Lama Pemeliharaan (hari).

Berdasarkan hasil pengamatan terhadap benih lele selama 56 hari masa pemeliharaan diketahui bahwa perbedaan tingkat penggunaan fermentasi BIS dalam pakan buatan menghasilkan pertambahan rata-rata bobot individu benih lele yang berbeda. Rata-rata laju pertumbuhan spesifik berat tertinggi $1.502 \%$ diperoleh dari benih lele yang diberi pakan buatan dengan tingkat penggunaan fermentasi BIS (8\%), sedangkan rata-rata laju pertumbuhan spesifik berat terendah diperoleh dari benih lele yang diberi pakan buatan dengan tingkat penggunaan BIS (12\%), yaitu sebesar $1.092 \%$.

Fermentasi BIS (8\%) menghasilkan bobot ikan tertinggi sebesar $1.502 \%$, dibandingkan dengan perlakuan fermentasi BIS (12\%) sebesar 1.35\%, Peningkatan laju pertumbuhan pada perlakuan (8\%) diduga karena fermentasi bungkil kelapa sawit menyumbang asam amino yang cukup lengkap ke dalam pakan sehingga dapat dicerna dengan baik oleh ikan. Kandungan asam amino dalam pakan dapat menunjang pertumbuhan ikan lele seperti keseimbangan kalsium dan fosfor yang terdapat dalam bungkil kelapa sawit. Selain itu, bungkil kelapa sawit yang difermentasi juga menurunkan kandungan serat kasar, sehingga ikan lebih mudah untuk mencernanya. Kemudian pemberian ransum yang sesuai dengan kebutuhan ikan, selain dapat menjamin kehidupan juga akan mempercepat pertumbuhan (Farida et al., 2016) Laju pertumbuhan panjang benih ikan lele berkisar $2.98 \%-4.06 \%$. Rata-rata laju pertumbuhan panjang harian benih ikan lele pada perlakuan A sebesar 3.83\%, dan perlakuan B sebesar 3.26\%. Hal ini sesuai dengan pendapat Effendi (1997), bahwa makanan yang telah mengalami fermentasi biasanya memiliki nilai gizi yang lebih tinggi dari asalnya. Laju pertumbuhan spesifik maupun laju pertumbuhan panjang harian. 
Berdasarkan tabel-8 diketahui bahwa pertumbuhan berat dan panjang berbanding lurus dalam setiap perlakuan. Selain itu dapat dilihat bahwa bobot rata-rata ikan mengalami peningkatan. Hal ini disebabkan karena pakan yang diberikan dimanfaatkan dengan baik oleh ikan. Didapat laju pertumbuhan yang berbeda pada kedua perlakuan menyebabkan bobot tubuh ikan lele juga berbeda setelah pemeliharaan. Effendi (1997) menyatakan bahwa pertumbuhan terjadi apabila ada kelebihan input energi dan asam amino (protein) yang berasal dari pakan.

Tabel 8. Laju pertumbuhan berat dan Panjang Ikan Selama Masa Pemeliharaan

\begin{tabular}{ccc}
\hline Perlakuan Pakan & Pertumbuhan Berat \% dan SD harian\% & $\begin{array}{c}\text { Pertumbuhan Panjang (\%) dan SD } \\
\text { harian (\%) }\end{array}$ \\
\hline A (Kandungan BIS 8\%) & $1.190 \pm 0.127$ & $3.83 \pm 0.44$ \\
B (Kandungan BIS 12\%) & $1.112 \pm 0.134$ & $3.26 \pm 0.25$ \\
\hline
\end{tabular}

Kecenderungan laju pertumbuhan berat dan pertumbuhan panjang ikan lebih tinggi pada ikan dengan pakan kandungan BIS 8\% dibandingkan kandungan BIS 12\%. Diduga hal ini ada hubungannaya dengan perbedaan perilaku kesukaan makan pada hewan karnivore dibandingkan ikan herbivore, karena BIS mengandung serat sebagai ciri kandungan dari tanaman/nabati.

Kemampuan kewirausahaan siswa dikategorikan baik, hal ini didapat dari hasil kemampuan siswa menghitung indikator terkait dengan aktivitas dari rancangan biaya yaitu Indikator dengan rata-rata skor tertinggi adalah memprediksi keuntungan.yaitu skor maksimum 25 dan terendah adalah memprediksi respons pengguna/masyarakat

Hasil rincian perhitungan analisis anggaran biaya operasional, modal awal dan hasil produksi maka 100\% siswa dapat menjawab benar. Selanjutnya didapat $50 \%$ siswa ( 2 kelompok dengan menggunakan pakan dengan komposisi BIS (8\%) pada kelompok A, selanjutnya dari analisis anggaran yaitu modal dan hasil panen selama pemeliharaan 3 bulan memperoleh keuntungan sebesar 30\%. Berarti 50\% siswa memperoleh keuntungan 30\% sedang 50\% (kelompok B) mendapat hasil seimbang antara pengeluaran dengan hasil panen. Hal ini diduga disebabkan komposisi BIS dapat mempengaruhi hasil produksi dan keuntungan dari hasil panen. Kemampuan memprediksi respons pengguna/masyarakat dikategorikan rendah, karena keterampilan berpikir menilai yang rendah. Hal ini sesuai dengan tingkat perkembangan berpikir (tipe C6) pada siswa dijenjang pendidikan di SMP.

Berdasarkan uraian di atas didapat hasil kegiatan P2M ini adalah kemampuan STEM siswa yaitu: kemampuan Sains dengan skor 85 (kategori baik), kemampuan Teknologi dengan skor 60 (kategori cukup), kemampuan Engineering dengan skor 50 (kategori kurang), dan kemampuan Matematika dengan skor 65 (kategori cukup). Kemampuan kewirausaahan dengan skor 75 (kategori baik) dan 50\% peserta mendapatkan keuntungan sebesar $30 \%$ dari produksi /panen Lele dalam waktu 3 bulan.

\section{KESIMPULAN DAN SARAN}

Kesimpulan kegiatan P2M ini adalah implementasi kemampuan siswa dalam mengintegrasikan kemampuan engineering, teknologi, matematika dengan sains yang cenderung kurang, namun siswa berpotensi dalam kemampuan sains dan kewirausahaan. Komposisi BIS (8\%) selama pemeliharaan 3 bulan memperoleh keuntungan sebesar 30\% pada 50\% siswa.

Perlu dilakukan kegiatan pengembangan lanjutan dan pendampingan dalam pembinaan mitra pada kemampuan implementasi STEM dan kewirausahaan budidaya lele misalnya efektif dan efisien konversi pakan pada pemeliharaan benih ikan lele, agar kemampuan STEM dan keuntungan ekonomi yang diperoleh lebih optimal.

\section{DAFTAR PUSTAKA}

Beers, S. 2011. 21st Century Skills: Preparing Students For Their Future. http://www.yinghuaacademy.org/wp content/ uploads/2014/10/21st-century-skills.pdf. Diakses pada tanggal 20 Mei 2019.

Denis, A. 2016. The Effectiveness of Science, Technology, Engineering and Mathematics (STEM) Learning Approach Among Secondary School Student. Universiti Malaysia Sabah

Effendie. 1997. Biologi Perikanan. Bogor: Yayasan Pustaka Purnama Nusatama. 
Ekasari, J. 2009. Teknologi Biotlok: Teori dan Aplikasi dalam Perikanan Budidaya Sistem Intensif. Jumal Akuakultur Indonesia 8(2): 117-126. https://pdfs.semanticscholar.org/9c90/2c70c8618c1de6a8fbf94cd6cd411adcce11.pdf

Farida, E., I. Raharjo, dan A. M. Sari. 2016. Substitusi Fermentasi Bungkil Kelapa Sawit dalam Pakan Buatan terhadap Pertumbuhan dan Kelangsungan Hidup Benih Ikan Gurami (Osphronemus gouramy). JURNAL RUAYA 4(1). https://doi.org/10.29406/rya.v4i1.686

Fitriadi, M. W., F. Basuki, dan R. A. Nugroho. 2014. Pengaruh Pemberian Recombinant Growth Hormone (rGH) Melalui Metode Oral dengan Interval Waktu yang Berbeda terhadap Kelulushidupan dan Pertumbuhan Larva Ikan Gurame var Bastard (Osphronemus gouramy Lac, 1801). Journal of Aquaculture Managment and Technology 3(2): 77-85. https://ejournal3.undip.ac.id/index.php/jamt/article/view/5065/4881

Handajani, H. 2006. Pemanfaatan Tepung Azolla sebagai Penyusun Pakan Ikan Terhadap Pertumbuhan dan Daya Cerna Ikan Nia Gift (Oreochromis sp.)., GAMMA 1(2): 162-170. http://ejournal.umm.ac.id/index.php/gamma/article/view/76/2886

KKP. 2013. Laporan Tahunan Direktorat Produksi Tahun 2013. http://www.djpb.kkp.go.id/public/ upload/download/Pustaka/06PUS TAKA/LAPTAH\%20PRODUKSI \%20\%202013.pdf. Diakses pada tanggal 20 Mei 2019.

Madinawati , N. S., dan Yoel. 2011. Pemberian Pakan yang Berbeda terhadap Pertumbuhan dan Kelangsungan Hidup Benih Ikan Lele Dumbo (Clarias gariepinus). Media Litbang Sulteng 4(2): 83-87. http://jurnal.untad.ac.id/jurnal/index.php/MLS/article/view/113/92

Mohapatra, S. B., dan A. K. Patra. 2013. Effect of Partial Replacement of Fishmeal with Duck Weed (Lemna minor) Feed On the Growth Performance of Cyprinus carpio Fry. Journal of Agriculture and Veterinary Science 4(2): 34-37. https://pdfs.semanticscholar.org/8ecc/bd074a585e03974642492d19e16781fb6787.pdf

Mudjiman, A. 2002. Makanan Ikan. Jakarta: Penebar Swadaya.

Sogbesan, O. A, C. F. Onoja, H. A. Adedeji, dan T. A. Idowu. 2015. Utilization of Treated Duckweed Meal (Lemna pausicostata) as Plant Protein Supplement in African Mud Catfish (Clarias gariepinus) Juvenile Diets. Fisheries and Aquaculture Journal 6(4): 1-5.

Sonata, M. A., M. Sulhi, dan Azrita. 2014. Subtisusi Tepung Kedelai dengan Tepung Enceng Gondok Hasil Fermentasi dalam Formulasi Pakan Terhadap Sintasan dan Pertumbuhan Benih Ikan Gurami (Osphronemus gouramy Lac). Skripsi Universitas Bung Hatta, Padang.

Yunus, T., Hasim, dan Rully. 2014. Pengaruh Padat Penebaran yang Berbeda terhadap Pertumbuhan Benih Ikan Lele Sangkuriang (Clarias gariepinus) di Balai Benih Ikan (BBI) Kota Gorontalo, Provinsi Gorontalo. KIM Fakultas Perikanan dan Ilmu Kelautan 2(3): 1-8. http://ejurnal.ung.ac.id/index.php/nike/article/download/1267/1016 